\title{
Bactericidal and virucidal efficacies of potassium monopersulfate and its application for inactivating avian influenza virus on virus-spiked clothes
}

\author{
Sorawot SONTHIPET ${ }^{1)}$, Sakchai RUENPHET ${ }^{1) *}$ and Kazuaki TAKEHARA ${ }^{2)}$ \\ ${ }^{1)}$ Immunology and Virology Department, Faculty of Veterinary Medicine, Mahanakorn University of Technology, \\ 140 Cheum-Sampan Rd., Nong Chock, Bangkok 10530, Thailand \\ 2)Laboratory of Animal Health, Department of Veterinary Medicine, Faculty of Agriculture, \\ Tokyo University of Agriculture and Technology, 3-5-8, Saiwai-cho, Fuchu-shi, Tokyo 183-8509, Japan
}

J. Vet. Med. Sci.

80(4): 568-573, 2018

doi: 10.1292/jvms.17-0599

Received: 15 November 2017 Accepted: 23 January 2018 Published online in J-STAGE: 12 February 2018
ABSTRACT. An acidic agent, potassium monopersulfate (PMPS), was evaluated for bactericidal and virucidal effects against Salmonella Infantis (SI), Escherichia coli, rifampicin-resistant Salmonella Infantis (SI-rif), Newcastle disease virus (NDV), and avian influenza virus (AIV), in the absence or presence of organic materials. In addition, inactivation activity toward a virus on virus-spiked clothes was also examined. PMPS could inactivate SI, E. coli, and SI-rif even in the presence of organic materials under various concentrations and exposure/contact time conditions. PMPS could also inactivate NDV and AIV. In addition, PMPS could inactivate AIV on a virus-spiked rayon sheet. In conclusion, the present study showed that PMPS has good antimicrobial properties against SI, E. coli, SI-rif, NDV, and AIV when used at the optimal dosage and exposure timing. These results suggest that PMPS could be used as an alternative disinfectant for biosecurity enhancement in animal farms or hospitals.

KEY WORDS: acidic agent, bactericidal, disinfectant, potassium monopersulfate, virucidal

Generally, foods derived from animal products, such as eggs, meat, and milk, have been implicated as vehicles of one or more of pathogens causing food-borne illness [3, 5, 6], especially Escherichia coli and Salmonella spp. In Japan, hazard analysis and critical control points (HACCP) have been introduced at animal farms for food safety [12]. One of the key points for HACCP is the appropriate usage of disinfectants to enhance biosecurity on and around animal farms.

Normally, poultry virus diseases such as Newcastle disease (ND) and avian influenza (AI), have a strong negative economic impact on the poultry industry. The viruses of both diseases are excreted in large amounts from the respiratory and digestive systems of clinically infected birds and contaminate the environment. Hence, an important aspect of disease control consists of proper cleaning and disinfection of the farm environment, which depends upon the use of an effective disinfectant agent. Many disinfectants are commercially available, and it is important to ensure that the disinfectant being used is effective against various pathogens.

The appropriate usage of disinfectants is critical for establishing a successful sanitation program. Because not all disinfectants are effective against major pathogens, different families of disinfectants that target specific microorganisms should be considered. For instance, several bacteria and viruses are sensitive to phenols; however, most bacteria are also sensitive to quaternary ammonium, iodophors, paracetic acid, glutaraldehydes, and cresols [2, 7]. Therefore, there is no single disinfectant reported in the literature that would be efficacious against a wide spectrum of etiological agents that economically impact diseases in animal farms. Moreover, special care should be taken when applying the disinfectant as it should be safe for both animals and humans. In addition, the hardness of water, correct dilutions, duration of contact with the pathogens, and the presence of organic material should also be taken into consideration.

The aim of the present study was to evaluate efficacies of potassium monopersulfate (PMPS) against Salmonella Infantis (SI), E. coli, rifampicin-resistant Salmonella Infantis (SI-rif), Newcastle disease virus (NDV), and avian influenza virus (AIV), in the absence or presence of organic materials, as well as to evaluate the inactivation activity of PMPS toward AIV on a rayon sheet for biosecurity applications in animal farms and animal hospitals.

*Correspondence to: Ruenphet, S.: rsakchai@hotmail.com

O2018 The Japanese Society of Veterinary Science

This is an open-access article distributed under the terms of the Creative Commons Attribution Non-Commercial No Derivatives (by-nc-nd) License. (CC-BY-NC-ND 4.0: https://creativecommons.org/licenses/by-nc-nd/4.0/) 


\section{MATERIALS AND METHODS}

\section{Sample preparation}

A potassium monopersulfate (PMPS) tablet (Lifejacket-T, KBNP, Chungnam, Korea), was freshly dissolved in sterile distilled water to reach PMPS concentrations of 5,000, 2,500, 1,250, 625 and $312.5 \mathrm{ppm}$.

\section{Pathogens, cells and media}

In the present study, E. coli strain NBRC106373, SI and SI-rif were used, after being prepared and enumerated as described previously [8]. These bacteria were sub-cultured onto deoxycholate hydrogen sulfide lactose (DHL) agar and then incubated at $37^{\circ} \mathrm{C}$ overnight. Bacterial colonies were picked and cultivated in Luria-Bertani (LB) medium ( $1 \%$ Bacto Tryptone, $0.5 \%$ Bacto Yeast Extract, and 1\% NaCl, pH 7.4) and titrated on DHL agar [13]. The cultured bacteria were washed to remove organic materials by centrifugation at $1,750 \times \mathrm{g}$ for $10 \mathrm{~min}$ and the resulted pellets were re-suspended in phosphate buffered saline (PBS) before use. In addition, the virulent NDV strain Sato and a low pathogenic AIV, namely A/duck/Aomori/Japan/395/2004 H7N1, were propagated in 9-day-old chicken embryonic eggs as previously described [9, 15]. After harvesting allantoic fluid, the viruses were aliquoted and kept at $-80^{\circ} \mathrm{C}$ until use. The chicken embryo fibroblast (CEF) and Madin-Darby canine kidney (MDCK) cells were used for NDV and AIV titration, respectively [9].

\section{Blocking solution preparation}

To neutralize the PMPS activity, a blocking solution was prepared by mixing $1 \mathrm{M}$ Tris- $\mathrm{HCl}(\mathrm{pH} 7.2)$ and fetal bovine serum (FBS) in a 7:1 ratio, to prepare $0.7 \mathrm{M}$ Tris- $\mathrm{HCl}$ and $30 \% \mathrm{FBS}$.

\section{Antimicrobial properties}

Four hundred microliters of PMPS solution was mixed with $100 \mu l$ of each pathogen, then incubated at room temperature $\left(25^{\circ} \mathrm{C}\right)$ for indicated time, namely $5 \mathrm{sec}, 30 \mathrm{sec}, 1 \mathrm{~min}, 3 \mathrm{~min}, 5 \mathrm{~min}, 10 \mathrm{~min}$ or $15 \mathrm{~min}$. After incubation, the solution mixture was neutralized with $500 \mu \mathrm{l}$ of the blocking solution, then titrated onto DHL agar plates for bacteria or onto MDCK cells and CEF for AIV and NDV, respectively. In order to represent the presence of organic materials at $5 \%, 500 \mu l$ of FBS was added to $10 \mathrm{~m} l$ of each PMPS solution sample before testing. To confirm the neutralizing efficacy of the blocking solution, it was added into each solution sample before adding the viruses or bacteria, namely at $0 \mathrm{sec}$. Each treatment was tested in triplicate, and the titers were shown as means and standard deviation (SD).

\section{Virucidal evaluation on contaminated surface}

The double-fold of rayon sheets (size $2 \times 2 \mathrm{~cm}^{2}$ ) were sterilized by autoclaving at $121^{\circ} \mathrm{C}$ for 15 min. To examine virucidal activity on the cloth, $100 \mu l$ of AIV was mixed with $50 \mu l$ of FBS to mimic AIV contamination in poultry excretions. The mixture was spotted on rayon sheets, which were then allowed to dry for $30 \mathrm{~min}$ at room temperature in a biosafety laboratory cabinet. After drying, the virus-spiked sheets were moved to microtubes containing $500 \mu l$ of PMPS solution or PBS for the negative control, and incubated for $5 \mathrm{sec}, 30 \mathrm{sec}, 1 \mathrm{~min}, 5 \mathrm{~min}, 10 \mathrm{~min}$ or $15 \mathrm{~min}$. The reaction was stopped by adding the blocking solution to the treated samples; virus titration was then performed on MDCK cells. In addition, the blocking solution was added before adding the spiked sheet to confirm the neutralizing efficacy on rayon sheets. This experiment was compared with the fourth generation of quaternary ammonium compounds, namely didecyl dimethyl ammonium bromide (DDAB) at dose of 500 ppm, the concentration recommended by the manufacturer (Bestaquam-S, China Bestar Laboratories Ltd., Taiwan). Each treatment was tested in triplicate, and the titers were shown as means with SD.

\section{Bacteria and virus titration and calculation}

Each treated bacterium was serially diluted 10-fold using PBS and inoculated onto DHL agar for bacterial titration. All inoculated petri dishes were incubated in an incubator at $37^{\circ} \mathrm{C}$, and the number of colonies was counted at $24 \mathrm{hr}$ post-inoculation. The bacterial titer was calculated in colony forming units (CFUs) $/ \mathrm{m} l$. In addition, NDV- and AIV-treated samples were serially diluted 10-fold using Eagle's minimum essential medium (MEM, Nissui Pharmaceutical Co., Ltd., Tokyo, Japan) containing 0.3\% of tryptose phosphate broth, penicillin $100 \mathrm{units} / \mathrm{ml}$, streptomycin $100 \mu \mathrm{g} / \mathrm{ml}$, amphotericin B $0.5 \mu \mathrm{g} / \mathrm{ml}$, and $4 \mathrm{mM} \mathrm{L-glutamine,}$ and then inoculated onto CEF or MDCK cells, respectively. However, before inoculation, MEM for AIV was added with trypsin (Trypsin, Sigma, St. Louis, MO, U.S.A.) to a final concentration of $0.2 \mu \mathrm{g} / \mathrm{m} l$. All of the inoculated tissue culture plates were incubated at $37^{\circ} \mathrm{C}$ in an incubator with $5 \% \mathrm{CO}_{2}$ and observed for cytopathic effects (CPEs) twice a day for 3 days. At the end of the incubation period, the hemagglutinin (HA) activity of the culture supernatant was detected using $0.5 \%$ chicken red blood cells. Finally, the $50 \%$ tissue culture infective dose $\left(\mathrm{TCID}_{50} / \mathrm{m} l\right)$ was determined by Behrens and Kärber's method [17].

\section{Inactivation analysis}

The reduction factor (RF) was used for determining the bacterial or viral inactivation. The RF was calculated using the following equation: $R F=t_{p c}-t_{a}$; where $t_{p c}$ is the titer converted into an index in $\log _{10}$ of the positive control and $t_{a}$ is the converted titer an index in $\log _{10}$ of the recovered bacteria or viruses from the treated sample. Bacterial or viral inactivation was considered effective when the RF was greater than or equal to $3 \log _{10}[10,16,17]$. 
Table 1. The $\mathrm{pH}$ (mean and SD) of potassium monopersulfate before and after neutralization with $1 \mathrm{M}$ Tris- $\mathrm{HCl}$

\begin{tabular}{cccccc}
\hline \multirow{2}{*}{$\begin{array}{c}\text { Concentration } \\
(\mathrm{ppm})\end{array}$} & \multicolumn{2}{c}{ Before neutralization } & & \multicolumn{2}{c}{ After neutralization } \\
\cline { 2 - 3 } \cline { 5 - 6 } & $\begin{array}{c}\text { Absence of organic } \\
\text { material }\end{array}$ & $\begin{array}{c}\text { Presence of organic } \\
\text { material }\end{array}$ & & $\begin{array}{c}\text { Absence of organic } \\
\text { material }\end{array}$ & $\begin{array}{c}\text { Presence of organic } \\
\text { material }\end{array}$ \\
\hline 5,000 & $2.04 \pm 0.05$ & $2.17 \pm 0.06$ & & $7.05 \pm 0.08$ & $7.11 \pm 0.05$ \\
2,500 & $2.28 \pm 0.06$ & $2.51 \pm 0.07$ & & $7.13 \pm 0.17$ & $7.21 \pm 0.04$ \\
1,250 & $2.54 \pm 0.06$ & $2.99 \pm 0.07$ & & $7.18 \pm 0.17$ & $7.24 \pm 0.10$ \\
625 & $2.82 \pm 0.06$ & $3.78 \pm 0.06$ & & $7.31 \pm 0.01$ & $7.31 \pm 0.01$ \\
312.5 & $3.10 \pm 0.05$ & $5.01 \pm 0.22$ & & $7.33 \pm 0.01$ & $7.33 \pm 0.02$ \\
\hline
\end{tabular}

\section{RESULTS}

The $\mathrm{pH}$ values of PMPS solutions at 5,000, 2,500, 1,250, 625 and $312.5 \mathrm{ppm}$ were measured before and after neutralization with the blocking solution by using a $\mathrm{pH}$ meter (Table 1). The corresponding $\mathrm{pH}$ values before neutralization in the absence of organic material were $2.04 \pm 0.05,2.28 \pm 0.06,2.54 \pm 0.06,2.82 \pm 0.06$ and $3.10 \pm 0.05$, respectively, whereas in the presence of organic materials the values were $2.17 \pm 0.06,2.51 \pm 0.07,2.99 \pm 0.07,3.78 \pm 0.06$ and $5.01 \pm 0.22$, respectively. However, the values after neutralization in the absence of organic material were $7.05 \pm 0.08,7.13 \pm 0.17,7.18 \pm 0.17,7.31 \pm 0.01$ and $7.33 \pm 0.01$, respectively, and in the presence of organic materials the values were $7.11 \pm 0.05,7.21 \pm 0.04,7.24 \pm 0.10,7.31 \pm 0.01$ and $7.33 \pm$ 0.02 , respectively.

Table 2 shows the bactericidal activity of PMPS against SI in the absence or presence of organic materials. At 5,000, 2,500, 1,250 and $625 \mathrm{ppm}$, PMPS could inactivate SI in the absence of organic materials within $5 \mathrm{sec}, 5 \mathrm{sec}, 30 \mathrm{sec}$ and $1 \mathrm{~min}$, respectively. At 5,000, 2,500 and 1,250 ppm, in the presence of 5\% FBS representing organic material contamination, inactivation occurred within $5 \mathrm{sec}, 5 \mathrm{sec}$ and $30 \mathrm{sec}$, respectively. However, at 625 and $312.5 \mathrm{ppm}$, PMPS could not inactivate SI regardless of $5 \%$ FBS.

The E. coli inactivation is shown in Table 3. At 5,000, 2,500, 1,250, 625 and $312.5 \mathrm{ppm}$ without organic material contamination, bactericidal activity occurred within $5 \mathrm{sec}, 5 \mathrm{sec}, 5 \mathrm{sec}, 30 \mathrm{sec}$ and $5 \mathrm{~min}$, respectively. Even in the presence of 5\% FBS, inactivation occurred at 5,000, 2,500, 1,250 and $625 \mathrm{ppm}$ within $5 \mathrm{sec}, 5 \mathrm{sec}, 30 \mathrm{sec}$, and $5 \mathrm{~min}$, respectively. However, at $312.5 \mathrm{ppm}$, with organic materials, PMPS could not inactivate E. coli within $15 \mathrm{~min}$.

The SI-rif inactivation activity by PMPS is shown in Table 4. At 5,000, 2,500, 1,250 and 625 ppm, PMPS could inactivate SI-rif in the absence of organic materials within $5 \mathrm{sec}, 5 \mathrm{sec}, 5 \mathrm{sec}$ and $30 \mathrm{sec}$, respectively. However, even in the presence $5 \%$ FBS, PMPS at 5,000, 2,500 and 1,250 ppm inactivated SI-rif within $5 \mathrm{sec}, 5 \mathrm{sec}$ and $30 \mathrm{sec}$, respectively.

The virucidal efficacies toward NDV and AIV are shown in Tables 5 and 6. PMPS at 5,000 and 2,500 ppm could inactivate NDV in the absence of organic material within $30 \mathrm{sec}$ and $5 \mathrm{~min}$, respectively, and in the presence of organic materials, inactivated NDV within 1 and $5 \mathrm{~min}$, respectively. However, PMPS at 1,250 ppm could not inactivate NDV even in the absence of organic materials within 15 min. Regarding AIV, PMPS at 5,000, 2,500 and 1,250 ppm could inactivate AIV even in the presence of organic materials within $5 \mathrm{sec}, 5 \mathrm{sec}$ and $30 \mathrm{sec}$, respectively. At $625 \mathrm{ppm}$, PMPS could inactivate AIV within 10 min in the absence of organic material; however, in the presence of organic material, it could not inactivate AIV within 15 min.

The AIV inactivating activity on infected rayon sheets compared between PMPS and recommendation dose of DDAB toward AIV contaminated with $33 \%$ organic materials is presented in Table 7. PMPS at 5,000, 2,500 and 1,250 ppm could inactivate AIV within $30 \mathrm{sec}, 5 \mathrm{~min}$ and $15 \mathrm{~min}$, respectively. However, the recommended dose of DDAB could not inactivate AIV on rayon sheets.

\section{DISCUSSION}

Titers of bacteria/virus control (tpc) before and after neutralization by Tris- $\mathrm{HCl}$ did not show marked inactivation, indicating that the blocking solution could neutralize the inactivation activity of PMPS. These findings demonstrate that this blocking solution can be used to stop the inactivation activity of PMPS at the contact times indicated for the present study.

PMPS is the potassium salt of peroxymonosulfuric acid, which is widely used as an oxidizing agent. This salt probably acts on bacteria by oxidation. It also attacks viral protein capsids, thereby releasing and inactivating the nucleic acids of viruses, thus affecting the bactericidal and virucidal efficacies under various concentrations, exposure/contact times, and organic material conditions. The results also indicated that bacteria were more sensitive than viruses to inactivation by PMPS. Several products, such as Oxone ${ }^{\circledR}$ and DupontTM, contain potassium monopersulfate for their main ingredient, as a non-chlorine shock agent; PMPS breaks the chorine-ammonia bond formed when chlorine combines with ammonia, without increasing the chlorine level of the swimming pool; hence, PMPS can be used in swimming pools to keep the water clear [14]. In addition, Virkon ${ }^{\circledR}$-S contains PMPS at $21.41 \%$ and has been used at concentrations of 5,000-20,000 ppm for multipurpose virucidal disinfection, with the greatest numbers of the Environmental Protection Agency (EPA Registration No. 71654-6)-registered claims, against pathogens affecting domestic and companion animals. However, The PMPS tablet in the present study was used at concentrations of 312.5-5,000 ppm; hence, this PMPS is confirmed for safety and toxicity towards animals and humans. 
Table 2. $\log _{10} \mathrm{CFU} / \mathrm{m} l($ mean $\pm \mathrm{SD})$ of Salmonella Infantis after treatment with potassium monopersulfate in the absence or presence of organic material

\begin{tabular}{|c|c|c|c|c|c|c|c|c|c|c|}
\hline & \multicolumn{2}{|c|}{$5,000 \mathrm{ppm}$} & \multicolumn{2}{|c|}{$2,500 \mathrm{ppm}$} & \multicolumn{2}{|c|}{$1,250 \mathrm{ppm}$} & \multicolumn{2}{|c|}{$625 \mathrm{ppm}$} & \multicolumn{2}{|c|}{$312.5 \mathrm{ppm}$} \\
\hline & Absence $^{\text {a) }}$ & Presence $^{\mathrm{b})}$ & Absence & Presence & Absence & Presence & Absence & Presence & Absence & Presence \\
\hline$\left.t_{p c} c\right)$ & $8.72 \pm 0.51$ & $8.72 \pm 0.51$ & $8.48 \pm 0.32$ & $8.48 \pm 0.32$ & $8.65 \pm 0.06$ & $8.48 \pm 0.32$ & $8.55 \pm 0.13$ & $8.65 \pm 0.06$ & $8.55 \pm 0.13$ & $8.65 \pm 0.06$ \\
\hline $\left.0 \sec ^{d}\right)$ & $8.50 \pm 0.47$ & $8.53 \pm 0.12$ & $7.73 \pm 1.63$ & $8.40 \pm 0.38$ & $8.49 \pm 0.15$ & $8.31 \pm 0.34$ & $8.47 \pm 0.27$ & $8.53 \pm 0.23$ & $8.45 \pm 0.14$ & $8.45 \pm 0.22$ \\
\hline $5 \mathrm{sec}^{\mathrm{e})}$ & $<2.60 \pm 0.00^{*}$ & $<2.60 \pm 0.00^{*}$ & $<2.60 \pm 0.00^{*}$ & $<2.60 \pm 0.00^{*}$ & $6.13 \pm 0.39$ & $6.75 \pm 0.52$ & NT & NT & NT & NT \\
\hline $30 \mathrm{sec}$ & $<2.60 \pm 0.00^{*}$ & $<2.60 \pm 0.00 *$ & $<2.60 \pm 0.00^{*}$ & $<2.60 \pm 0.00^{*}$ & $3.09 \pm 0.85^{*}$ & $3.19 \pm 1.03 *$ & $6.95 \pm 0.86$ & NT & NT & NT \\
\hline $1 \mathrm{~min}$ & NT & NT & NT & NT & NT & NT & $5.00 \pm 1.12 *$ & NT & $7.60 \pm 0.00$ & NT \\
\hline $5 \mathrm{~min}$ & NT & NT & NT & NT & NT & NT & $5.20 \pm 0.38^{*}$ & NT & $6.24 \pm 0.02$ & NT \\
\hline $10 \mathrm{~min}$ & NT & NT & NT & NT & NT & NT & $4.61 \pm 0.94 *$ & $6.36 \pm 0.56$ & $5.74 \pm 0.37$ & $7.28 \pm 0.52$ \\
\hline $15 \mathrm{~min}$ & NT & NT & NT & NT & NT & NT & $5.33 \pm 0.71 *$ & $6.21 \pm 0.58$ & $5.65 \pm 0.09$ & $7.06 \pm 0.58$ \\
\hline
\end{tabular}

a) Absence of organic material. b) Presence of organic material. c) The titer converted into an index in $\log _{10}$ of bacterial control. d) Blocking solution added before addition of Salmonella Infantis. e) The titer converted into an index in $\log _{10}$ of the recovered virus after indicated duration of treatment such as 5 sec, $30 \mathrm{sec}, 1 \mathrm{~min}, 5 \mathrm{~min}, 10 \mathrm{~min}$ and $15 \mathrm{~min}$. NT: Not tested. Inactivation regarded as effective when RF was greater than or equal to 3.

Table 3. $\log _{10} \mathrm{CFU} / \mathrm{m} l$ (mean $\pm \mathrm{SD}$ ) of Escherichia coli after treatment with potassium monopersulfate in the absence or presence of organic material

\begin{tabular}{|c|c|c|c|c|c|c|c|c|c|c|}
\hline & \multicolumn{2}{|c|}{$5,000 \mathrm{ppm}$} & \multicolumn{2}{|c|}{$2,500 \mathrm{ppm}$} & \multicolumn{2}{|c|}{$1,250 \mathrm{ppm}$} & \multicolumn{2}{|c|}{$625 \mathrm{ppm}$} & \multicolumn{2}{|c|}{$312.5 \mathrm{ppm}$} \\
\hline & Absence $^{a)}$ & Presence ${ }^{\mathrm{b})}$ & Absence & Presence & Absence & Presence & Absence & Presence & Absence & Presence \\
\hline$t_{p c} c^{\prime}$ & $9.10 \pm 0.23$ & $9.07 \pm 0.21$ & $8.31 \pm 0.58$ & $8.31 \pm 0.58$ & $8.31 \pm 0.58$ & $8.31 \pm 0.58$ & $8.31 \pm 0.58$ & $8.55 \pm 0.42$ & $8.55 \pm 0.42$ & $8.26 \pm 0.50$ \\
\hline $0 \sec ^{\mathrm{pc}}$ & $9.03 \pm 0.41$ & $8.76 \pm 0.10$ & $8.21 \pm 0.09$ & $8.07 \pm 0.25$ & $8.04 \pm 0.35$ & $7.66 \pm 0.76$ & $7.97 \pm 0.55$ & $8.39 \pm 0.35$ & $8.27 \pm 0.55$ & $7.72 \pm 1.27$ \\
\hline $5 \mathrm{sec}^{\mathrm{e})}$ & $3.30 \pm 1.20^{*}$ & $4.08 \pm 1.31^{*}$ & $<2.60 \pm 0.00^{*}$ & $3.84 \pm 1.37^{*}$ & $3.53 \pm 1.60^{*}$ & $5.46 \pm 0.69$ & $7.45 \pm 1.01$ & NT & NT & NT \\
\hline $30 \mathrm{sec}$ & $<2.60 \pm 0.00^{*}$ & $<2.60 \pm 0.00 *$ & $<2.60 \pm 0.00 *$ & $<2.60 \pm 0.00^{*}$ & $3.17 \pm 0.98 *$ & $<2.60 \pm 0.00^{*}$ & $4.41 \pm 0.29^{*}$ & $7.39 \pm 0.48$ & $7.26 \pm 0.76$ & NT \\
\hline $1 \mathrm{~min}$ & NT & NT & NT & NT & NT & NT & $<2.60 \pm 0.00^{*}$ & $7.03 \pm 0.69$ & $6.99 \pm 0.55$ & NT \\
\hline $5 \mathrm{~min}$ & NT & NT & NT & NT & NT & NT & NT & $5.14 \pm 1.10^{*}$ & $5.32 \pm 0.25^{*}$ & NT \\
\hline $10 \mathrm{~min}$ & NT & NT & NT & NT & NT & NT & NT & $4.74 \pm 0.64 *$ & $4.86 \pm 0.68^{*}$ & $5.35 \pm 0.83$ \\
\hline $15 \mathrm{~min}$ & NT & NT & NT & NT & NT & NT & NT & NT & NT & $6.06 \pm 0.45$ \\
\hline
\end{tabular}

a) Absence of organic material. b) Presence of organic material. c) The titer converted into an index in $\log _{10}$ of bacterial control. d) Blocking solution added before addition of Escherichia coli. e) The titer converted into an index in $\log _{10}$ of the recovered virus after indicated duration of treatment such as $5 \mathrm{sec}, 30 \mathrm{sec}$, $1 \mathrm{~min}, 5 \mathrm{~min}, 10 \mathrm{~min}$ and $15 \mathrm{~min}$. NT: Not tested. *Inactivation regarded as effective when RF was greater than or equal to 3.

Table 4. $\log _{10} \mathrm{CFU} / \mathrm{m} l$ (mean $\pm \mathrm{SD}$ ) of Rifampicin-resistant Salmonella Infantis after treatment with potassium monopersulfate in the absence and presence of organic material

\begin{tabular}{|c|c|c|c|c|c|c|c|c|c|c|}
\hline & \multicolumn{2}{|c|}{$5,000 \mathrm{ppm}$} & \multicolumn{2}{|c|}{$2,500 \mathrm{ppm}$} & \multicolumn{2}{|c|}{$1,250 \mathrm{ppm}$} & \multicolumn{2}{|c|}{$625 \mathrm{ppm}$} & \multicolumn{2}{|c|}{$312.5 \mathrm{ppm}$} \\
\hline & Absence $^{\text {a) }}$ & Presence $^{\text {b) }}$ & Absence & Presence & Absence & Presence & Absence & Presence & Absence & Presence \\
\hline$\left.t_{p c}^{c}\right)$ & $8.64 \pm 0.10$ & $8.64 \pm 0.10$ & $8.64 \pm 0.10$ & $8.64 \pm 0.10$ & $8.61 \pm 0.04$ & $8.61 \pm 0.04$ & $8.61 \pm 0.04$ & $8.61 \pm 0.04$ & $8.59 \pm 0.04$ & $8.59 \pm 0.04$ \\
\hline $0 \mathrm{sec}^{\mathrm{d})}$ & $8.52 \pm 0.21$ & $8.63 \pm 0.12$ & $8.57 \pm 0.04$ & $8.67 \pm 0.09$ & $8.66 \pm 0.15$ & $8.60 \pm 0.16$ & $8.39 \pm 0.15$ & $8.36 \pm 0.23$ & $8.49 \pm 0.06$ & $8.50 \pm 0.08$ \\
\hline $5 \mathrm{sec}^{\mathrm{e})}$ & $<2.60 \pm 0.00 *$ & $2.94 \pm 0.58^{*}$ & $3.17 \pm 0.98^{*}$ & $3.38 \pm 1.35^{*}$ & $4.67 \pm 1.79 *$ & $7.20 \pm 0.65$ & $7.33 \pm 0.31$ & NT & NT & NT \\
\hline $30 \mathrm{sec}$ & $<2.60 \pm 0.00^{*}$ & $<2.60 \pm 0.00^{*}$ & $<2.60 \pm 0.00^{*}$ & $<2.60 \pm 0.00^{*}$ & $3.82 \pm 2.10^{*}$ & $5.67 \pm 1.74$ & $4.93 \pm 0.40^{*}$ & NT & NT & NT \\
\hline $1 \mathrm{~min}$ & NT & NT & NT & NT & NT & $3.65 \pm 1.82 *$ & $3.76 \pm 2.00^{*}$ & NT & NT & NT \\
\hline $5 \mathrm{~min}$ & NT & NT & NT & NT & NT & NT & NT & NT & NT & NT \\
\hline $10 \mathrm{~min}$ & NT & NT & NT & NT & NT & NT & NT & $6.26 \pm 1.25$ & $6.14 \pm 0.05$ & $7.80 \pm 0.03$ \\
\hline $15 \mathrm{~min}$ & NT & NT & NT & NT & NT & NT & NT & $6.03 \pm 1.10$ & $5.96 \pm 0.15$ & $7.70 \pm 0.03$ \\
\hline
\end{tabular}

a) Absence of organic material. b) Presence of organic material. c) The titer converted into an index in $\log _{10}$ of bacterial control. d) Blocking solution added before addition of Salmonella Infantis. e) The titer converted into an index in $\log _{10}$ of the recovered virus after indicated duration of treatment such as 5 sec, $30 \mathrm{sec}, 1 \mathrm{~min}, 5 \mathrm{~min}, 10 \mathrm{~min}$ and $15 \mathrm{~min}$. NT: Not tested. *Inactivation regarded as effective when RF was greater than or equal to 3 .

Generally, bacteria and viruses are highly resistant to disinfectants contained in bio-environmental constituents such as feces, saliva, or vomitus [4]. In addition, viruses can survive on the surfaces of materials, fomites, and food for long periods [1, 11]. Our model of evaluating virus inactivation involved utilizing rayon sheets to simulate carpets, bedding, towels, or cloths contaminated with viruses and containing organic materials. In addition, several quaternary ammonium compounds have been reported to exhibit broad-spectrum virucidal activity, including in the present study that used rayon; therefore, considering the cloth savings and its efficacy, DDAB was selected for comparison with PMPS. As shown in Table 7, 5,000, 2,500 and 1,250 ppm of PMPS could inactivate AIV, while DDAB could not inactivate this virus on rayon sheets at the recommended dose. These results suggest that PMPS can be applied as a disinfectant or a virucidal agent that can inactivate AIV in contaminated carpets, clothes, towels, or bedding, especially in animal farms or hospitals. 
Table 5. $\log _{10} \mathrm{TCID}_{50} / \mathrm{ml}$ (mean $\pm \mathrm{SD}$ ) of Newcastle disease virus after treatment with potassium monopersulfate in the absence or presence of organic material

\begin{tabular}{|c|c|c|c|c|c|c|}
\hline & \multicolumn{2}{|c|}{$5,000 \mathrm{ppm}$} & \multicolumn{2}{|c|}{$2,500 \mathrm{ppm}$} & \multicolumn{2}{|c|}{$1,250 \mathrm{ppm}$} \\
\hline & Absence $^{a)}$ & Presence $^{\text {b) }}$ & Absence & Presence & Absence & Presence \\
\hline$\left.t_{p c}^{c}\right)$ & $7.08 \pm 0.63$ & $6.92 \pm 0.38$ & $8.63 \pm 0.18$ & $8.63 \pm 0.18$ & $8.63 \pm 0.18$ & $8.63 \pm 0.18$ \\
\hline $\left.0 \sec ^{d}\right)$ & $7.33 \pm 0.80$ & $6.75 \pm 0.25$ & $8.50 \pm 0.00$ & $8.38 \pm 0.53$ & $8.63 \pm 0.18$ & $8.50 \pm 0.00$ \\
\hline $5 \mathrm{sec}^{\mathrm{e})}$ & $6.25 \pm 0.90$ & $5.92 \pm 0.58$ & $7.88 \pm 0.18$ & $8.00 \pm 0.00$ & $8.38 \pm 0.18$ & $8.63 \pm 0.18$ \\
\hline $30 \mathrm{sec}$ & $3.50 \pm 0.50 *$ & $4.25 \pm 0.25$ & $6.75 \pm 1.06$ & $7.63 \pm 0.88$ & $8.00 \pm 0.00$ & $8.50 \pm 0.71$ \\
\hline $1 \mathrm{~min}$ & $2.92 \pm 0.72 *$ & $2.75 \pm 0.43^{*}$ & $5.75 \pm 0.35$ & $7.13 \pm 0.18$ & $8.00 \pm 0.35$ & $8.38 \pm 0.53$ \\
\hline $5 \mathrm{~min}$ & NT & NT & $<3.50 \pm 0.00^{*}$ & $<3.50 \pm 0.00 *$ & $7.88 \pm 0.53$ & $8.38 \pm 0.88$ \\
\hline $10 \mathrm{~min}$ & NT & NT & $<3.50 \pm 0.00^{*}$ & $<3.50 \pm 0.00 *$ & $6.88 \pm 0.18$ & $7.88 \pm 0.53$ \\
\hline $15 \mathrm{~min}$ & NT & NT & $<3.50 \pm 0.00^{*}$ & $<3.50 \pm 0.00^{*}$ & $5.88 \pm 0.18$ & $7.63 \pm 0.18$ \\
\hline
\end{tabular}

a) Absence of organic material. b) Presence of organic material. c) The titer converted into an index in $\log _{10}$ of virus control. d) Added blocking solution before addition of Newcastle disease virus. e) The titer converted into an index in $\log _{10}$ of the recovered virus after indicated time of treatment such as $5 \mathrm{sec}, 30 \mathrm{sec}, 1 \mathrm{~min}, 5 \mathrm{~min}, 10 \mathrm{~min}$ and $15 \mathrm{~min}$. NT: Not tested. *Inactivation regarded as effective when RF was greater than or equal to 3 .

Table 6. $\log _{10} \mathrm{TCID}_{50} / \mathrm{ml}($ mean $\pm \mathrm{SD})$ of Avian influenza virus after treatment with potassium monopersulfate in the absence or presence of organic material

\begin{tabular}{|c|c|c|c|c|c|c|c|c|c|c|}
\hline & \multicolumn{2}{|c|}{$5,000 \mathrm{ppm}$} & \multicolumn{2}{|c|}{$2,500 \mathrm{ppm}$} & \multicolumn{2}{|c|}{$1,250 \mathrm{ppm}$} & \multicolumn{2}{|c|}{$625 \mathrm{ppm}$} & \multicolumn{2}{|c|}{$312.5 \mathrm{ppm}$} \\
\hline & Absence $^{\text {a) }}$ & Presence $^{\mathrm{b})}$ & Absence & Presence & Absence & Presence & Absence & Presence & Absence & Presence \\
\hline$\left.t_{p c} c\right)$ & $7.33 \pm 0.29$ & $7.33 \pm 0.29$ & $7.75 \pm 0.38$ & $7.75 \pm 0.38$ & $7.50 \pm 0.25$ & $7.50 \pm 0.25$ & $7.67 \pm 0.14$ & $7.67 \pm 0.14$ & $7.42 \pm 0.38$ & $7.42 \pm 0.38$ \\
\hline $\left.0 \sec ^{d}\right)$ & $7.00 \pm 0.25$ & $7.25 \pm 0.25$ & $7.50 \pm 0.25$ & $7.42 \pm 0.38$ & $7.50 \pm 0.25$ & $7.92 \pm 0.14$ & $7.50 \pm 0.50$ & $7.00 \pm 0.43$ & $7.67 \pm 0.29$ & $7.50 \pm 0.43$ \\
\hline $5 \mathrm{sec}^{\mathrm{e})}$ & $<2.50 \pm 0.00^{*}$ & $2.92 \pm 0.72 *$ & $<2.50 \pm 0.00^{*}$ & $3.08 \pm 1.01 *$ & $4.75 \pm 0.00$ & $7.13 \pm 0.53$ & NT & NT & NT & NT \\
\hline $30 \mathrm{sec}$ & $<2.50 \pm 0.00^{*}$ & $2.75 \pm 0.43^{*}$ & $<2.50 \pm 0.00^{*}$ & $2.67 \pm 0.29^{*}$ & $3.67 \pm 1.81^{*}$ & $3.58 \pm 1.66^{*}$ & NT & NT & NT & NT \\
\hline $1 \mathrm{~min}$ & NT & NT & NT & $<2.50 \pm 0.00^{*}$ & $2.67 \pm 0.14^{*}$ & $2.58 \pm 0.14^{*}$ & NT & NT & NT & NT \\
\hline $5 \mathrm{~min}$ & NT & NT & NT & NT & NT & NT & $5.83 \pm 0.58$ & $7.08 \pm 0.14$ & NT & NT \\
\hline $10 \mathrm{~min}$ & NT & NT & NT & NT & NT & NT & $3.67 \pm 1.81^{*}$ & $7.08 \pm 0.38$ & $7.00 \pm 0.25$ & $7.42 \pm 0.38$ \\
\hline $15 \mathrm{~min}$ & NT & NT & NT & NT & NT & NT & $2.75 \pm 0.43 *$ & $7.00 \pm 0.25$ & $6.92 \pm 0.38$ & $7.58 \pm 0.38$ \\
\hline
\end{tabular}

a) Absence of organic material. b) Presence of organic material. c) The titer converted into an index in $\log _{10}$ of virus control. d) Blocking solution added before addition of Avian influenza virus. e) The titer converted into an index in $\log _{10}$ of the recovered virus after indicated duration of treatment such as $5 \mathrm{sec}, 30 \mathrm{sec}$, $1 \mathrm{~min}, 5 \mathrm{~min}, 10 \mathrm{~min}$ and $15 \mathrm{~min}$. NT: Not tested. * Inactivation regarded as effective when RF was greater than or equal to 3 .

Table 7. $\log _{10} \mathrm{TCID}_{50} / \mathrm{m} l($ mean $\pm \mathrm{SD})$ of Avian influenza virus after treatment on an infected rayon sheet compared between potassium monopersulfate and recommendation dose of didecyl dimethyl ammonium bromide in viruses contaminated with $33 \%$ organic material

\begin{tabular}{rcccc}
\hline & \multicolumn{3}{c}{ Potassium monopersulfate } & $\begin{array}{c}\text { Didecyl dimethyl ammonium bromide } \\
\text { recommendation dose as 500 ppm }\end{array}$ \\
\cline { 2 - 4 } & $5,000 \mathrm{ppm}$ & $2,500 \mathrm{ppm}$ & $1,250 \mathrm{ppm}$ & $7.42 \pm 0.14$ \\
$\mathrm{t}_{\mathrm{pc}}^{\mathrm{a}}$ & $7.25 \pm 0.25$ & $7.08 \pm 0.14$ & $7.08 \pm 0.14$ & $6.83 \pm 0.29$ \\
$0 \mathrm{sec}^{\mathrm{b})}$ & $6.83 \pm 0.58$ & $6.58 \pm 0.38$ & $6.67 \pm 0.14$ & $\mathrm{NT}$ \\
$5 \mathrm{sec}^{\mathrm{c})}$ & $5.42 \pm 0.63$ & $6.08 \pm 0.58$ & $\mathrm{NT}$ & $\mathrm{NT}$ \\
$30 \mathrm{sec}$ & $3.92 \pm 0.72^{*}$ & $5.25 \pm 0.43$ & $\mathrm{NT}$ & $\mathrm{NT}$ \\
$1 \mathrm{~min}$ & $4.08 \pm 1.38^{*}$ & $4.17 \pm 0.88$ & $\mathrm{NT}$ & $6.42 \pm 0.14$ \\
$5 \mathrm{~min}$ & $2.58 \pm 0.14^{*}$ & $2.58 \pm 0.14^{*}$ & $5.00 \pm 0.87$ & $6.33 \pm 0.52$ \\
$10 \mathrm{~min}$ & $\mathrm{NT}$ & $<2.50 \pm 0.00^{*}$ & $5.25 \pm 0.25$ & $5.58 \pm 1.26$ \\
$15 \mathrm{~min}$ & $\mathrm{NT}$ & $\mathrm{NT}$ & $3.42 \pm 1.15^{*}$ &
\end{tabular}

a) The titer converted into an index in $\log _{10}$ of virus control. b) Blocking solution added before addition of Avian influenza virus.

c) The titer converted into an index in $\log _{10}$ of the recovered virus after indicated duration of treatment such as $5 \mathrm{sec}, 30 \mathrm{sec}$, $1 \mathrm{~min}, 5 \mathrm{~min}, 10 \mathrm{~min}$ and $15 \mathrm{~min}$. NT: Not tested. *Inactivation regarded as effective when RF was greater than or equal to 3 .

In conclusion, PMPS can inactivate bacteria and viruses either in the absence or presence of organic materials, and can be useful as an alternative disinfectant, especially for biosecurity enhancement aiming to control bacteria and viruses that contaminate animal farms and hospitals. 
ACKNOWLEDGMENTS. The authors thank VET AGRITECH Co., Ltd. for providing potassium monopersulfate (PMPS) tablets for this experiment, as well as Dr. Dany Shoham at Bar Ilan University, Israel, for a grammatical review of the manuscript. This work was supported in part by a grant-in-aid from the Veterinary Medicine Faculty, Mahanakorn University of Technology, Thailand and Faculty of Agriculture, Tokyo University of Agriculture and Technology.

\section{REFERENCES}

1. Barclay, L., Park, G. W., Vega, E., Hall, A., Parashar, U., Vinjé, J. and Lopman, B. 2014. Infection control for norovirus. Clin. Microbiol. Infect. 20: 731-740 [CrossRef]. [Medline]

2. Bermudez, A. J. 2008. Principles of disease prevention: diagnosis and control. pp. 3-42. In: Diseases of Poultry. 12th ed. (Saif, Y. M., Fadly, A. M., Glisson, J. R., MacDougald, L., Nolan, L. K. and Swayne, D. F. eds.), Blackwell Publishing, Iowa.

3. Beuchat, L. R. 1995. Pathogenic microorganisms associated with fresh produce. J. Food Prot. 59: 204-216. [CrossRef]

4. Bloomfield, S. F., Exner, M., Signorelli, C., Nath, K. J. and Scott, E. A. 2011. The infection risks associated with clothing and household linens in home and everyday life settings, and the role of laundry. International Scientific Forum on Home Hygiene. https://www.ifh-homehygiene.org/bestpractice-review/infection-risks-associated-clothing-and-household-linens-home-and-everyday-life [accessed on April 7, 2011].

5. D'Aoust, J. 1997. Food Microbiology: Fundamentals and Frontiers. American Society for Microbiology, Washington, D.C.

6. Doyle, M. P., Zhao, T., Meng, J. and Zhao, S. 1997. Escherichia coli O157:H7-Food Microbiology: Fundamentals and Frontiers. American Society for Microbiology, Washington, D.C.

7. Gradel, K. O., Sayers, A. R. and Davies, R. H. 2004. Surface disinfection tests with Salmonella and a putative indicator bacterium, mimicking worst-case scenarios in poultry houses. Poult. Sci. 83: 1636-1643. [Medline] [CrossRef]

8. Hakim, H., Alam, M. S., Sangsriratanakul, N., Nakajima, K., Kitazawa, M., Ota, M., Toyofuku, C., Yamada, M., Thammakarn, C., Shoham, D. and Takehara, K. 2016. Inactivation of bacteria on surfaces by sprayed slightly acidic hypochlorous acid water: in vitro experiments. J. Vet. Med. Sci. 78: 1123-1128. [Medline] [CrossRef]

9. Jahangir, A., Ruenphet, S., Shoham, D., Okamura, M., Nakamaura, M. and Takehara, K. 2010. Haemagglutinin and neuraminidase characterization of low pathogenic $\mathrm{H} 5$ and $\mathrm{H} 7$ avian influenza viruses isolated from Northern pintails (Anas acuta) in Japan, with special reference to genomic and biogeographical aspects. Virus Genes 40: 94-105. [Medline] [CrossRef]

10. Lombardi, M. E., Ladman, B. S., Alphin, R. L. and Benson, E. R. 2008. Inactivation of avian influenza virus using common detergents and chemicals. Avian Dis. 52: 118-123. [Medline] [CrossRef]

11. Malik, Y. S., Allwood, P. B., Hedberg, C. W. and Goyal, S. M. 2006. Disinfection of fabrics and carpets artificially contaminated with calicivirus: relevance in institutional and healthcare centres. J. Hosp. Infect. 63: 205-210 [CrossRef]. [Medline]

12. Ministry of Agriculture Forestry and Fisheries 2017. The improvement of the breeding hygiene management standard in the stage of production of the domestic animal. http://www.maff.go.jp/j/syouan/douei/katiku_yobo/k_haccp/index.html [accessed Febuary 20, 2017].

13. Ota, M., Toyofuku, C., Thammakarn, C., Sangsriratanakul, N., Yamada, M., Nakajima, K., Kitazawa, M., Hakim, H., Alam, M. S., Shoham, D. and Takehara, K. 2016. Calcinated egg shell as a candidate of biosecurity enhancement material. J. Vet. Med. Sci. 78: 831-836. [Medline] [CrossRef]

14. Shukur, S. A. and Adnan, S. A. 2016. Water quality measuring in swimming pools by oxidation reduction potential method. Int. J. Res. 3: 553-576.

15. Takehara, K., Shinomiya, T., Kobayashi, H., Azuma, Y., Yamagami, T. and Yoshimura, M. 1987. Characterization of Newcastle disease viruses isolated from field cases in Japan. Avian Dis. 31: 125-129. [Medline] [CrossRef]

16. Takehara, K., Yamazaki, K., Miyazaki, M., Yamada, Y., Ruenphet, S., Jahangir, A., Shoham, D., Okamura, M. and Nakamura, M. 2010. Inactivation of avian influenza virus H1N1 by photocatalyst under visible light irradiation. Virus Res. 151: 102-103. [Medline] [CrossRef]

17. Thammakarn, C., Satoh, K., Suguro, A., Hakim, H., Ruenphet, S. and Takehara, K. 2014. Inactivation of avian influenza virus, newcastle disease virus and goose parvovirus using solution of nano-sized scallop shell powder. J. Vet. Med. Sci. 76: 1277-1280. [Medline] [CrossRef] 